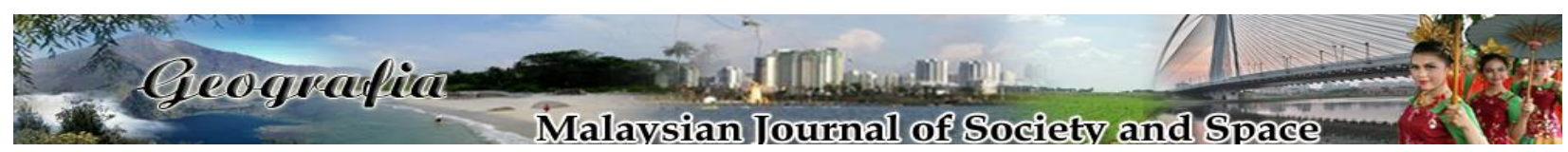

\title{
Analisis tahap kepuasan pengunjung di taman rekreasi awam Sabah
}

\author{
Rosniza Aznie Che Rose ${ }^{1}$, Nur Efazainiza Ainie Basri ${ }^{1}$ \\ ${ }^{1,2}$ Program Geografi, Pusat Pembangunan, Sosial dan Persekitaran, \\ Fakulti Sains Sosial dan Kemanusiaan, Universiti Kebangsaan Malaysia \\ Corresspondent: Rosniza Aznie Che Rose (email: aznie@ukm.edu.my)
}

Received: 15 November 2019; Accepted: 22 November 2019; Published: 25 November 2019

\begin{abstract}
Abstrak
Penyediaan landskap di sesebuah taman rekreasi awam merupakan salah satu kemudahan yang disediakan oleh Pihak Berkuasa Tempatan (PBT) khususnya kepada komuniti bandar. Pengurusan landskap yang baik dan berkualiti akan mempengaruhi kunjungan dan tahap kepuasan pengunjung. Walau bagaimanapun, pengurusan landskap di kebanyakan taman awam secara umumnya masih berada pada tahap yang rendah. Sehubungan dengan itu, kajian yang dijalankan ini adalah berkenaan dengan pengurusan landskap di Taman Ujana Rimba Tropika dalam konteks penerimaan pengunjung. Terdapat tiga objektif dalam kajian ini iaitu mengenal pasti profil kedatangan pengunjung, menganalisis tahap kepuasan pengunjung terhadap pengurusan landskap dan mencadangkan langkah penambahbaikan terhadap pengurusan landskap di Taman Ujana Rimba Tropika. Kaedah kajian yang digunakan adalah pemerhatian, temu bual tidak rasmi dan borang soal selidik yang diedarkan kepada 210 orang responden dan pemilihan sampel dilakukan menggunakan formula Taro Yamanae. Data kajian dianalisis menggunakan analisis deskriptif frekuensi, Cross-Tabulation dan Chi-Square serta analisis korelasi melalui perisian Statistical Package for Sosial Sciences. Berdasarkan hasil kajian, didapati bahawa kunjungan ulangan pengunjung secara majoritinya adalah disebabkan oleh penyediaan landskap lembut memberi suasana yang tenang, tarikan semula jadi yang menarik, lokasi yang strategik serta untuk melakukan aktiviti senaman di mana nilai min yang diperoleh adalah tinggi. Secara keseluruhan, tahap kepuasan responden terhadap pengurusan landskap di Taman Ujana Rimba Tropika adalah pada tahap sederhana. Oleh yang demikian, sesebuah taman rekreasi awam perlu dilengkapi dengan kemudahan-kemudahan yang dapat menjamin kepuasan pengunjung seiring dengan keperluan semasa pengunjung.
\end{abstract}

Kata Kunci: landskap, pengunjung, pengurusan landskap, taman rekreasi, taman awam 


\title{
Analysis of visitor satisfaction levels in Sabah recreational public parks
}

\begin{abstract}
Providing landscaping in a public recreational park is one of the services provided by the Local Authority (PBT) especially to the urban community. Good and quality landscape management will influence the level of visitor satisfaction. However, landscape management in most public parks is generally low. In this regard, this study focused towards the visitor satisfaction from their experienced in Sabah public Parks. The objectives in this study are, to identify the profile of visitor arrivals, to analyze the level of visitor satisfaction with landscape management and to suggest improvements to landscape management in the Sabah Public Parks. The research method used was observation, informal interview and questionnaire form distributed to 210 respondents. The sample selection was conducted using Taro Yamanae formula. The data were analyzed using Descriptive Frequency Analysis, Cross-Tabulation and Chi-Square as well as correlation analysis using Statistical Package for Social Sciences software. Based on the results, it was found that the return visitors were mainly due to the provision of a soft landscape providing a calm atmosphere, attractive natural attractions, and trategic location for exercise activities where the mean value was high. Overall, the respondents' satisfaction with the management of the landscape in the public park was moderate. Therefore, a public recreational park should be equipped with facilities that guarantee the satisfaction of visitors in line with the current needs of the visitors.
\end{abstract}

Keywords: landscape, visitors, landscape management, recreation park, public park

\section{Pengenalan}

Taman rekreasi awam merupakan salah satu kemudahan fasiliti yang perlu disediakan oleh Pihak Berkuasa Tempatan (PBT) khususnya kepada komuniti bandar. Menurut Kamariyah (1983), taman rekreasi ini haruslah mempunyai ciri-ciri tertentu seperti pembelajaran, nilai estetika dan juga budaya kerana tidak semua kawasan lapang adalah sesuai untuk dijadikan sebuah taman rekreasi. Namun begitu, pada masa kini pelbagai masalah wujud di kebanyakan taman rekreasi awam termasuklah di Taman Rekreasi Awam Sabah yang memberi fokus kepada Taman Ujana Rimba Tropika. Keadaan ini boleh dilihat melalui perubahan khususnya dalam aspek kemudahan awam yang terdapat di taman tersebut. Dengan itu, pengurusan landskap adalah sangat penting dan memerlukan kerjasama semua pihak termasuklah pengunjung dan komuniti yang berhampiran.

Pembangunan landskap dalam konteks pembangunan landskap di Malaysia merangkumi pembinaan landskap di sesebuah taman awam. Secara umumnya, taman merupakan tanah lapang yang juga dikenali sebagai kawasan rekreasi awam, tempat awam, taman bunga awam atau sebagai tempat untuk bersiar-siar (Garis Panduan Landskap Negara, 2008). Taman awam boleh didefinisikan sebagai satu landskap yang dibina oleh pihak berkuasa di sesebuah tanah lapang bagi tujuan aktiviti rekreasi orang awam yang dipenuhi dengan pelbagai kemudahan dan kelengkapan. Bukan itu sahaja, taman awam juga merupakan tempat pelbagai aktiviti rekreasi dan berseronok dalam keadaan yang selesa bagi tujuan untuk berehat khususnya bagi memulihkan ketegangan psikologi dan jasmani. 
Taman Ujana Rimba Topika atau Taman Hutan Hujan adalah satu lagi tempat rekreasi popular yang boleh didapati di Kota Kinabalu. Taman ini terletak di Jalan Penampang dan kirakira empat kilometer dari pusat bandar. Ia adalah lokasi yang strategik kerana berhampiran dengan Perpustakaan Negeri Sabah, Jabatan Arkib Negeri, Jabatan Geokimia, Hospital Queen Elizabeth, Jabatan Pertanian dan Perikanan dan beberapa buah taman perumahan. Namun begitu, Taman Ujana Rimba Tropika ini mengalami masalah dari segi pengurusan landskap dan telah memberi kesan kepada imejnya sebagai kawasan tumpuan pengunjung sama ada dari dalam dan luar negara. Menurut Pelan Induk Landskap Wilayah Persekutuan Labuan (1997-2015), didapati bahawa pengurusan dan penyelenggaraan landskap taman awam di Malaysia masih berada di tahap yang rendah. Sebagai contoh, elemen landskap seperti peralatan permainan, trek joging dan siar kaki yang disediakan di kebanyakan taman rekreasi awam telah rosak dan terbiar ekoran daripada kelemahan dalam aspek pengurusan dan penyelenggaraan daripada pihak berkuasa. Justeru itu, Dasar Landskap Negara (DLN) yang digunakan adalah penting dalam memandu serta menyediakan hala tuju bagi pembangunan landskap negara. Bagi mencapai hasrat negara dalam mencapai matlamat untuk membangunkan landskap Malaysia yang baik dan unik, maka sesuatu perlaksanaan pembangunan haruslah dilaksanakan dengan terancang di samping sistem pengurusan landskap negara yang berkesan.

\section{Perkembangan pembangunan dan pengurusan landskap di Malaysia}

Pembangunan landskap kemudiannya terus berkembang dan ia dikaitkan dengan sejarah hasil peninggalan penjajah iaitu Belanda, Portugis dan British. Mereka ini dikatakan telah memperkenalkan konsep rekreasi dan kawasan lapang. Antara peninggalan kawasan rekreasi yang wujud sejak zaman penjajah adalah seperti Taman Botani, Pulau Pinang yang wujud pada tahun 1884 lagi. Selain itu, Taman Tasik Perdana Kuala Lumpur 1888 juga merupakan salah satu taman rekreasi yang masih wujud sehingga kini. Tambahan lagi, penjajah pada ketika itu turut membawa masuk tumbuhan eksotik daripada negara mereka untuk dijadikan sebagai salah satu elemen landskap pada ketika itu. Kemudian, pembangunan landskap terus berkembang ke tanah Melayu yang bermula di kawasan perkampungan orang Melayu. Landskap pada zaman tersebut berbeza dengan landskap yang ada pada masa kini kerana landskap yang wujud di perkampungan orang Melayu lebih kepada unsur-unsur semula jadi khususnya tumbuhtumbuhan. Tumbuh-tumbuhan ini dijadikan sebagai elemen landskap terutamanya di kawasan lapang (Sejarah Landskap, 2011).

Seterusnya, pembangunan landskap di Malaysia semakin diambil perhatian melalui pembangunan landskap yang lebih tersusun dan teratur pada akhir tahun 1970-an. Pada akhir tahun 1970-an, usaha pembangunan landskap dikembangkan melalui pengindahan kawasan kediaman, jalan raya, bangunan-bangunan awam serta taman-taman rekreasi. Pembangunan landskap terutamanya di taman rekreasi awam terus berkembang dengan mewujudkan lebih banyak kawasan rekreasi dan kawasan lapang untuk kemudahan orang awam.

Kesedaran untuk mewujudkan lebih banyak taman awam dan kawasan lapang menyebabkan wujudnya undang-undang khas yang menetapkan setiap pembangunan yang ingin dijalankan di negara ini harus mempunyai landskap yang baik merangkumi semua aspek persekitaran. Antara peruntukan undang-undang dan garis panduan berkaitan dengan landskap adalah Akta Perancang Bandar dan Desa, 1976. Bahagian VA iaitu undang-undang yang berkaitan dengan penanaman pokok di kawasan lapang dan juga taman rekreasi awam. Selain daripada perlaksanaan undang- 
undang, Garis Panduan Landskap Negara, 1995 juga dilaksanakan bagi tujuan penerapan elemen-elemen landskap sebagai penyeri dan meningkatkan lagi keindahan persekitaran.

Pada tahun 1996, Jabatan Landskap Negara (JLN) ditubuhkan sebagai agensi yang berperanan dalam hal-hal berkaitan khidmat nasihat dan kawal selia bagi pembangunan landskap di seluruh negara. Hal ini kerana, kerajaan menyasarkan Malaysia akan menjadi sebuah negara yang memiliki pembangunan landskap yang mampu melahirkan persekitaran atau suasana kehidupan yang harmoni di samping kehidupan yang lebih berkualiti demi kesejahteraan rakyat. Justeru itu, melalui penubuhan Jabatan Landskap Negara ini pelbagai usaha yang dilaksanakan bagi mewujudkan suasana landskap yang indah. Ekoran daripada penubuhan Jabatan Landskap Negara ini, satu dasar telah digubal iaitu Dasar Landskap Negara (DLN) dengan matlamat menjadikan Malaysia sebuah Negara Taman Terindah menjelang 2020.

Dasar Landskap Negara ini merupakan satu panduan operasi yang komprehensif dalam meningkatkan lagi kualiti kehidupan alam sekitar. Ia selaras dengan matlamat pembangunan negara yang berhasrat untuk menerapkan elemen landskap dalam sesebuah pembangunan fizikal agar pembangunan di negara ini seimbang dari segi ekonomi dan alam sekitar. Oleh yang demikian, penggubalan Dasar Landskap Negara ini jelas meletakkan kepentingan pembangunan landskap sebagai satu keperluan dalam sesebuah pembangunan fizikal negara. Rasional pembangunan landskap ini dijalankan adalah agar pembangunan ekonomi di negara ini terus dijalankan tanpa mengabaikan tanggungjawab dan kepentingan untuk terus memelihara, memulihara dan mengekalkan sumber alam semula jadi di Malaysia (Dasar Landskap Negara, 2010).

Bagi mencapai pembangunan landskap negara yang terancang dan berkualiti, maka pengurusan landskap perlu dilaksanakan bagi memastikan kerja-kerja dalam merangka dan melaksanakan pembangunan landskap dilakukan secara teratur. Tambahan lagi, pengurusan landskap juga perlu mengambil kira semua aspek seperti elemen semula jadi dan buatan manusia. Menurut Lee (2000), bagi memastikan sesebuah taman atau kawasan diurus dan di selenggara dengan baik serta berkesan maka kerjasama daripada Pihak Kerajaan Negeri dan Pihak Berkuasa Tempatan (PBT) diperlukan agar dapat memandu pembangunan landskap yang boleh dinikmati oleh orang ramai. Oleh yang demikian, sesebuah projek atau pembangunan landskap yang ingin dijalankan perlulah melalui penapisan mengikut peringkat seperti peringkat daerah, negeri, kementerian, agensi pusat dan jemaah menteri. Tanpa pengurusan landskap yang teratur ia boleh mengakibatkan berlakunya kelewatan dan masalah dalam melaksanakan sesebuah pembangunan landskap.

\section{Pengurusan landskap di taman rekreasi awam}

Taman rekreasi atau juga dikenali sebagai taman awam merupakan kawasan yang dibangunkan untuk memenuhi keperluan kawasan lapang yang memenuhi kepentingan serta mampu berfungsi di samping dapat memberi manfaat kepada pengguna. Penyediaan kemudahan rekreasi yang dapat memenuhi keperluan masyarakat adalah sejajar dengan aspirasi Wawasan 2020 yang bertujuan menjadikan Malaysia sebagai negara maju, industri dan pada masa yang sama mempunyai kualiti hidup yang tinggi. Penyediaan kemudahan rekreasi ini juga merupakan salah satu usaha menyahut cabaran Kerajaan untuk menjadikan Malaysia sebagai Taman Negara menjelang tahun 2005. Dengan adanya keperluan taman awam ini maka pengurusan yang terancang dan sistematik perlu dilaksanakan. Umumnya, pengurusan melibatkan proses 
perancangan, penyusunan, pengarahan dan pengawalan dengan menggunakan sumber yang merangkumi sumber manusia, kewangan dan juga teknologi. Justeru itu, pengurusan haruslah menjamin bahawa nilai pelbagai gunaan atau kemudahan rekreasi itu dalam keadaan yang baik, selamat dan berterusan (Wan Sabri et al., 1983).

Berdasarkan kajian yang dijalankan oleh Hamidi et al. (2006), beliau menyatakan bahawa perlunya pengurusan tarikan pelawat ke sesuatu kawasan kerana dengan adanya tarikan pelawat ke sesuatu kawasan akan menyumbang kepada permintaan terhadap kemudahan sokongan dan aktiviti-aktiviti yang dilakukan. Kedatangan pelawat ke sesuatu kawasan lazimnya akan memberi impak sama ada kesan positif mahupun negatif. Penyataan ini disokong oleh Johan Afendi (2006) yang menyatakan kesan tersebut boleh dibahagikan kepada tiga iaitu kesan ke atas ekonomi, sosial dan alam sekitar. Pelancongan secara lestari mampu mengurangkan kesan ekologi dan sosiobudaya kepada masyarakat setempat (Zaimah et al., 2018; Jeckie \& Greg, 2018). Oleh yang demikian, pengurusan dalam tarikan pelawat ke sesuatu kawasan perlu dibuat dengan terancang dan efisien. Bagi memastikan kemasukan pelawat yang berterusan, maka konsep pelancongan lestari juga perlu di ambil kira kerana ia bukan sahaja dapat mewujudkan sebuah pembangunan yang mampu meminimumkan kesan negatif. Malah ia juga dapat mencegah daripada berlakunya penurunan kemasukan pengunjung secara mendadak.

Berbeza pula dengan kajian yang dijalankan oleh Rosniza Aznie (2017) mengenai potensi tarikan ekopelancongan rekreasi di Taman Rekreasi Air Panas (TRAP) Sungai Klah, Perak. Kajian ini bukan sahaja bertujuan untuk mengetahui potensi TRAP Sungai Klah, Perak tetapi turut meneliti aktiviti rekreasi dan daya tarikannya. Selain itu, ia juga bertujuan untuk menilai kemudahan yang disediakan di samping menilai persepsi pelancong terhadap TRAP. Kebanyakan pelancong yang datang ke TRAP bertujuan untuk mandi-manda, merebus telur, melihat keindahan flora dan fauna serta banyak lagi aktiviti rekreasi yang boleh dijalankan. Berdasarkan kepada penilaian pelancong terhadap kemudahan dan persekitaran yang disediakan, secara keseluruhannya berada di tahap yang memuaskan tetapi kemudahan yang disediakan harus ditambah, diperbaiki, dan dipertingkatkan dari semasa ke semasa untuk memenuhi keperluan dan keselesaan pengunjung agar terus meningkat. Namun begitu, terdapat kemudahan yang mendapat respon negatif daripada pengunjung seperti kemudahan telefon, tempat permainan kanak-kanak dan kemudahan jalan yang tidak memuaskan.

\section{Masalah pengurusan kawasan lapang dan kawasan rekreasi di Malaysia}

Seperti yang sedia maklum, penyediaan kawasan lapang yang berkualiti di sesebuah kawasan bandar adalah sangat penting dalam mewujudkan suasana bandar yang sejahtera. Justeru itu, penyediaan kawasan lapang di Malaysia haruslah mengikut Garis Panduan Kawasan Lapang dan Rekreasi yang telah disediakan oleh Jabatan Perancangan Bandar dan Desa. Pengurusan kawasan lapang di kawasan bandar adalah di bawah tanggungjawab Pihak Berkuasa Tempatan (PBT) yang berperanan dalam memastikan kawasan lapang yang disediakan boleh dirancang dan diagihkan di lokasi-lokasi yang sesuai.

Menurut Carson (1972), adalah sukar untuk mendapatkan tanah di kawasan bandar yang boleh digunakan di lokasi yang tepat, pada masa yang sesuai, dalam kuantiti yang mencukupi, dan setimpal dengan harga pembangunan yang diperlukan. Ia disebabkan oleh ketersediaan tanah di kawasan bandar merupakan masalah kritikal yang sering dialami. Selain itu, pembangunan yang kian pesat menyumbang kepada kawasan bandar yang tepu dan padat disebabkan oleh 
kekurangan tanah untuk dibangunkan. Disebabkan itu, kebanyakan pihak PBT menghadapi masalah dalam menyediakan kawasan lapang kerana menghadapi masalah ketersediaan tanah yang bersesuaian untuk dijadikan kawasan rekreasi awam. Oleh kerana kawasan bandar mengalami masalah kekurangan ruang dan tanah, penyediaan lebih banyak taman hijau di taman kawasan poket di dalam kawasan bandar boleh menjadi dilema penyelesaian untuk menyediakan taman awam yang besar (Putri Haryati, 2015).

Antara masalah lain yang dihadapi dalam pengurusan kawasan lapang adalah disebabkan ketidakpatuhan pemaju mengenai polisi kawasan lapang. Melasutra (1998) menyatakan bahawa telah menjadi perkara biasa bagi pihak pemaju menyediakan kawasan lapang dan bukan ruang lapang. Masalah timbul apabila kawasan lapang sering digunakan bagi tujuan menutup kawasankawasan yang kurang pada pelan (Salingaros, 2005). Hal ini berlaku disebabkan mereka merasa bahawa kawasan lapang tidak mempunyai kepentingan dalam aspek perancangan sesuatu kawasan. Penyediaan kawasan lapang yang dibuat di sesuatu kawasan hanya sekadar memenuhi syarat-syarat kebenaran merancang (Idris, 2010). Bukan itu sahaja, kawasan lapang turut diletakkan di tempat yang tidak sesuai sehingga menjadikan kawasan tersebut tidak berfungsi. Ia bertentangan dengan matlamat sebenar dalam menyediakan kawasan lapang kepada orang ramai kerana kawasan lapang perli disediakan kerana ia berfungsi sebagai tempat untuk bersosial, berekreasi dan berinteraksi. Justeru itu, kawasan lapang perlu dijaga dan pihak yang bertanggungjawab harus mematuhi syarat-syarat yang dinyatakan dalam dasar sedia ada.

Menurut Rooslinda (2002), tahap penyelenggaraan yang rendah juga menyebabkan pengurusan sesebuah kawasan rekreasi sering mengalami masalah. Tidak dinafikan bahawa masalah vandalisme dalam kalangan masyarakat semakin berleluasa terutamanya di kawasan rekreasi sehingga menyebabkan kawasan rekreasi mempunyai kurang daya tarikan, usang dan mencemarkan pemandangan. Selain itu, pelbagai kemudahan di beberapa taman rekreasi dan permainan kanak-kanak di ibu negara yang rosak akibat perbuatan vandalisme masih belum dibaik pulih sehingga kini (Utusan Online, 2015). Hal ini secara tidak langsung menyebabkan kehadiran pengunjung yang semakin berkurang. Perbuatan negatif segelintir masyarakat seperti mencemarkan kawasan lapang menyebabkan kawasan lapang menjadi kotor dan usang. Masalah dalam sistem penyelenggaraan dan pengurusan taman-taman rekreasi oleh pihak berkuasa tempatan menyebabkan kawasan lapang kurang diselenggarakan.

\section{Metod kajian}

Sampel yang dipilih adalah terdiri daripada pengunjung tempatan yang berkunjung ke Taman Ujana Rimba Tropika. Pemilihan responden menggunakan teknik persampelan bertujuan berdasarkan ciri-ciri yang telah ditetapkan oleh penyelidik mengikut objektif kajian. Berdasarkan hasil temu bual bersama salah seorang pegawai Jabatan Landskap iaitu Encik Ahmad Jalani bin Mahari, anggaran pengunjung yang datang ke Taman Ujana Rimba Tropika adalah seramai 400 orang pengunjung. Data bagi anggaran jumlah pengunjung ini disokong melalui pengiraan yang dibuat oleh pengkaji di mana pengkaji turun ke lapangan untuk membuat pengiraan jumlah pengunjung yang berkunjung pada waktu puncak. Justeru itu, pemilihan sampel kajian dalam kajian ini adalah berdasarkan kepada formula Taro Yamanae (1967). Saiz sampel kajian yang digunakan dalam kajian ini adalah dengan nisbah 0.5 yang mewakili aras keyakinan (e) iaitu sebanyak 210 orang pengunjung. 
Data-data yang diperoleh ini akan dianalisis menggunakan analisis deskriptif frekuensi seperti kekerapan, peratusan dan min. Selain itu, analisis yang digunakan adalah analisis CrossTabulation dan Chi Square serta analisis korelasi. Analisis yang dilakukan ini kemudiannya dipersembahkan dalam bentuk dan kaedah yang sesuai.

\section{Hasil kajian}

Jadual 1 menunjukkan hasil dapatan mengenai profil responden yang telah dipilih semasa pengedaran borang soal selidik dan kemudiannya dianalisis. Responden yang dipilih dalam kajian ini adalah responden yang terdiri daripada pengunjung yang berkunjung ke Taman Ujana Rimba. Justeru itu, jadual di atas merupakan hasil dapatan yang meliputi profil responden yang terdiri daripada jantina, umur, agama, status perkahwinan, taraf pendidikan, pekerjaan, pendapatan bulanan dan tempat tinggal responden. Secara ringkasnya, majoriti responden bagi kajian ini adalah responden lelaki iaitu sebanyak 123 orang responden berumur dalam lingkungan umur 36 hingga 45 tahun. Bagi agama responden pula, majoriti responden adalah beragama Islam iaitu sebanyak 90 orang. Selain itu rata-rata responden adalah responden yang telah berkahwin iaitu sebanyak 129 orang. Dari segi taraf pendidikan pula, majoriti responden mempunyai taraf pendidikan sehingga SPM dan diploma iaitu masing-masing sebanyak 66 orang responden. Manakala, dari segi status pekerjaan responden, kebanyakan daripada responden bekerja sebagai kakitangan swasta iaitu sebanyak 60 orang. Pendapatan bulanan bagi majoriti responden pula adalah antara RM 1001 hingga RM 2000. Berdasarkan kepada hasil dapatan bagi tempat tinggal responden, ia menunjukkan bahawa kebanyakan responden merupakan responden yang tinggal berhampiran dengan kawasan kajian iaitu Taman Ujana Rimba Tropika. Bilangan responden tertinggi adalah dalam kalangan responden yang tinggal di sekitar Penampang iaitu sebanyak 60 orang daripada jumlah keseluruhan responden.

Jadual 1. Profil responden

\begin{tabular}{lc}
\hline Profil Responden & Jumlah \\
\hline Jantina & 123 \\
Lelaki & 87 \\
Perempuan & \\
Umur & 39 \\
$18-25$ tahun & 48 \\
$26-35$ tahun & 63 \\
$36-45$ tahun & 48 \\
$46-55$ tahun & 12 \\
56 tahun ke atas & \\
Agama & \\
Islam & 90 \\
Kristian & 69 \\
Buddha & 51 \\
Status Perkahwinan & \\
Berkahwin & 129 \\
Bujang & 81 \\
Taraf Pendidikan & 39 \\
Ijazah & 66 \\
Diploma & 66 \\
Sijil/SPM & \\
\hline
\end{tabular}




\begin{tabular}{lc}
\hline PMR & 3 \\
Pernah bersekolah tetapi tidak tamat & 36 \\
Pekerjaan & \\
Kakitangan awam & 51 \\
Kakitangan Swasta & 60 \\
Pesara & 42 \\
Pelajar & 33 \\
Tiada pekerjaan & 24 \\
Pendapatan bulanan & \\
< RM 1000 & \\
RM 1001- RM 2000 & 9 \\
RM 2001- RM 3000 & 72 \\
RM 3001- RM 4000 & 48 \\
Tiada pendapatan & 24 \\
Tempat tinggal & 57 \\
Kepayan & \\
Kinarut & 6 \\
Kota Kinabalu & 6 \\
Luyang & 24 \\
Penampang & 39 \\
Petagas & 60 \\
Putatan & 9 \\
Sembulan & 27 \\
Tanjung Aru & 33 \\
\end{tabular}

Sumber: Kajian lapangan pada Oktober, 2018

\section{Profil kedatangan pengunjung ke Taman Ujana Rimba Tropika}

Berdasarkan hasil kajian yang diperoleh, profil kedatangan pengunjung ke Taman Ujana Rimba adalah berbeza-beza. Bagi tujuan utama berkunjung, majoriti responden yang berkunjung ke Taman Ujana Rimba Tropika adalah bertujuan untuk bersenam atau berjoging di mana ia mencatatkan peratusan tertinggi iaitu sebanyak 37.1 peratus. Hasil daripada pemerhatian pengkaji, ia jelas menunjukkan bahawa Taman Ujana Rimba Tropika sering menjadi tumpuan pengunjung untuk berjoging memandangkan kawasan taman ini adalah luas dan sesuai untuk melakukan aktiviti yang melibatkan senaman. Manakala, bagi profil kekerapan berkunjung pula menunjukkan rata-rata responden berkunjung ke Taman Ujana Rimba Tropika sebanyak sekali seminggu iaitu sebanyak 27.1 peratus responden. Hal ini kerana, berdasarkan latar belakang responden, kebanyakan daripada mereka adalah golongan yang telah bekerja. Oleh yang demikian, kebanyakan responden yang berkunjung ke taman tersebut adalah pada waktu hujung minggu atau semasa cuti umum. Seterusnya, dari segi cara kedatangan responden ke Taman Ujana Rimba Tropika pula menunjukkan majoriti responden menaiki kenderaan sendiri kerana ianya lebih praktikal yang mudah untuk sampai ke taman tersebut. Bagi responden yang menaiki kenderaan sendiri ini, ia mencatatkan peratusan yang sangat tinggi iaitu sebanyak 80 peratus daripada jumlah keseluruhan responden. Selain itu, masa berkunjung responden juga adalah berbeza-beza mengikut masa lapang responden. Hasil kajian yang diperoleh mendapati rata-rata responden dalam kajian ini gemar untuk berkunjung pada waktu petang iaitu sebanyak 64.3 peratus. Ia bukan sahaja dipengaruhi oleh faktor cuaca yang mendung malah kebanyakan responden pada waktu tersebut telah pulang dari bekerja. Berdasarkan maklum balas daripada responden, waktu mereka berkunjung adalah sekitar pukul 3.30 hingga 5.00 petang. Selain daripada itu, terdapat lokasi-lokasi tertentu yang sering dikunjungi oleh responden. Justeru itu, 
hasil kajian mendapati lokasi yang sering dikunjungi oleh responden adalah kawasan trek joging iaitu sebanyak 28.6 peratus. Hal ini berkait rapat dengan tujuan utama kedatangan pengunjung yang mana majoriti daripada bertujuan untuk berjoging.

Faktor kunjungan ulangan yang pertama bagi majoriti responden adalah lokasi yang strategik. Lokasi yang strategik ini dikaitkan dengan lokasi yang memudahkan pengunjung untuk sampai ke taman. Sebanyak 58.6 peratus responden yang menyatakan setuju dan nilai min adalah sebanyak 3.80 iaitu pada tahap yang tinggi. Selain itu, faktor kunjungan ulangan responden juga adalah disebabkan oleh faktor landskap lembut yang memberi suasana yang lebih tenang iaitu sebanyak 66.7 peratus responden menyatakan setuju. Manakala, berdasarkan kepada nilai min ia menunjukkan nilai min yang tinggi iaitu 4.01. Sesuai dengan kajian yang dijalankan oleh Nur Fateha (2015) di mana pemandangan landskap yang dihiasi dengan pokok-pokok yang ditanam di sekitar taman rekreasi dapat memberi suasana yang aman dan damai. Seterusnya, tarikan alam semula jadi seperti tumbuhan dan pokok-pokok juga merupakan salah satu tarikan utama di sesuatu tempat (Jaffry \& Nor Azlina, 2004). Hasil kajian yang diperoleh menunjukkan tarikan semula jadi yang menarik juga merupakan faktor kunjungan ulangan pengunjung di mana sebanyak 61.4 responden menyatakan setuju dan nilai min adalah 3.84 iaitu pada tahap yang tinggi. Selain itu, faktor kunjungan ulangan pengunjung juga adalah disebabkan responden menjalankan aktiviti senaman sebagai rutin harian. Sebanyak 45.7 peratus responden menyatakan setuju dan nilai min bagi penyataan ini adalah 3.67 iaitu tinggi. Hal ini kerana, menurut McLean (2012), melalui senaman dan aktiviti rekreasi, seseorang individu dapat melepaskan diri dari rutin harian yang memberi tekanan dan melupakan masalah. Tambahan lagi, aktiviti fizikal seperti bersenam dan berjoging adalah salah satu kesan positif terhadap perkembangan pengetahuan tentang kesihatan fizikal dalam kalangan masyarakat.

\section{Tahap kepuasan pengunjung terhadap pengurusan landskap di Taman Ujana Rimba Tropika}

Pengurusan landskap yang dimaksudkan adalah terdiri daripada beberapa item iaitu secara ringkasnya ia merangkumi 17 komponen atau item yang terdiri daripada pengurusan landskap lembut dan landskap kejur (Jadual 2). Landskap lembut adalah seperti tumbuh-tumbuhan hijau yang terdapat di Taman Ujana Rimba Tropika. Manakala, landskap kejur adalah kemudahankemudahan fizikal yang disediakan di Taman Ujana Rimba Tropika untuk kemudahan pengunjung.

Berdasarkan Jadual 2, terdapat beberapa item yang menunjukkan tahap kepuasan responden adalah pada tahap yang tinggi iaitu pengurusan landskap lembut, keadaan dan kebersihan kawasan untuk aktiviti yoga, serta penyediaan tong sampah. Majoriti responden berpuas hati dengan pengurusan landskap lembut kerana tumbuh-tumbuhan hijau dan hiasan seperti bungabungaan sememangnya menambahkan lagi keindahan landskap taman tersebut di mana nilai min adalah 3.81. Selain itu, ia juga melahirkan suasana yang lebih tenang di samping menyumbang kepada udara persekitaran yang bersih dan segar (Ramkissoon et al., 2018). Kawasan lapang yang disediakan untuk aktiviti yoga juga memberi tahap kepuasan yang tinggi dalam kalangan responden iaitu nilai min adalah 3.86. Hal ini kerana kebersihan di sekitar kawasan untuk aktiviti tersebut sentiasa dalam keadaan yang baik. Seterusnya, ha2sil analisis juga menunjukkan tahap kepuasan responden adalah tinggi bagi item penyediaan tong sampah di mana nilai min adalah 3.70. Berdasarkan pemerhatian pengkaji, bilangan tong sampah yang disediakan di sekitar Taman Ujana Rimba Tropika sememangnya mencukupi. Penyediaan tong sampah ini bukan sahaja memudahkan pengunjung untuk membuang sampah malah menjamin kebersihan taman 
sentiasa dalam keadaan yang baik dan bebas daripada pencemaran sampah sarap yang dibuang oleh pengunjung.

Hasil kajian yang telah dilakukan ini juga menunjukkan bahawa terdapat beberapa perkara atau elemen yang perlu diberi perhatian memandangkan terdapat dua item yang menunjukkan tahap kepuasan pengunjung adalah berada di tahap yang rendah iaitu tandas awam dan kebersihannya serta pengurusan surau dan kebersihannya. Bagi kemudahan tandas awam, ratarata responden menyatakan mereka tidak berpuas hati di mana nilai min adalah 2.33 . Hal ini disebabkan tandas awam tidak kerap dibersihkan kerana tiada kakitangan yang bertugas untuk menjaga dan membersihkan tandas tersebut. Keadaan ini menyebabkan responden tidak berpuas hati kerana ia menyebabkan tandas tersebut berbau busuk dan tidak selesa untuk digunakan. Manakala, tahap kepuasan yang menunjukkan nilai min yang paling rendah adalah tahap kepuasan pengunjung terhadap pengurusan surau dan kebersihannya kerana kemudahan beribadat seperti surau tidak disediakan di Taman Ujana Rimba Tropika. Oleh yang demikian, majoriti responden terutamanya yang beragama Islam tidak berpuas hati kerana penyediaan surau merupakan keperluan bagi pengunjung yang beragama Islam.

Jadual 2. Tahap kepuasan pengunjung terhadap pengurusan landskap di Taman Ujana Rimba Tropika

\begin{tabular}{lcc}
\hline Item & Min & Tahap \\
\hline Penyediaan landskap taman & 3.66 & Sederhana \\
Pengurusan dan kebersihan tasik & 2.60 & Sederhana \\
Kemudahan alat senaman & 2.49 & Sederhana \\
Kemudahan alat permainan & 2.99 & Sederhana \\
Pengurusan landskap lembut & 3.81 & Tinggi \\
Keadaan dan kebersihan kawasan untuk aktiviti yoga & 3.86 & Tinggi \\
Pengurusan keselamatan & 2.94 & Sederhana \\
Tempat letak kenderaan & 2.86 & Sederhana \\
Tandas awam dan tahap kebersihannya & 2.33 & Rendah \\
Pengurusan tempat makan dan kebersihannya & 3.01 & Sederhana \\
Tempat duduk dan meja untuk pengunjung & 3.34 & Sederhana \\
Kawasan trek jogging & 3.17 & Sederhana \\
Penyediaan tong sampah & 3.70 & Tinggi \\
Penambahbaikan peralatan/kemudahan yang rosak & 2.80 & Sederhana \\
Pengurusan surau dan kebersihannya & 1.80 & Rendah \\
& & \\
Pengurusan kemudahan untuk Orang Kurang Upaya & 2.39 & Sederhana \\
(OKU) & & \\
Kemudahan siar kaki pengunjung & 3.33 & Sederhana \\
Min Keseluruhan & $\mathbf{3 . 0 0}$ & Sederhana \\
\hline
\end{tabular}

Sumber: Kajian lapangan pada Oktober, 2018

Berdasarkan hasil dapatan melalui analisis Cross Tabulation dan Chi Square yang dilakukan terhadap beberapa item yang dipilih oleh pengkaji, terdapat beberapa item yang menunjukkan hubungan yang signifikan berdasarkan pemboleh ubah umur. Item tersebut adalah pengurusan tempat makan dan kebersihannya, pengurusan surau dan kebersihannya serta pengurusan kemudahan untuk Orang Kurang Upaya (OKU). Hasil analisis bagi ketiga-tiga item ini menunjukkan terdapat hubungan yang signifikan di mana nilai signifikan adalah lebih kecil berbanding dengan nilai signifikan yang digunakan $(\mathrm{p}<.05)$ iaitu nilai signifikan masing-masing adalah 0.003, 0.013 dan 0.046. Oleh yang demikian, berdasarkan hasil analisis ini ia 
menunjukkan terdapat hubungan signifikan antara item yang dipilih dengan pemboleh ubah umur. Seterusnya, analisis korelasi (r) juga digunakan dalam kajian ini untuk menganalisis kekuatan hubungan antara tahap kepuasan pengunjung terhadap pengurusan landskap dengan faktor kunjungan ulangan pengunjung ke Taman Ujana Rimba Tropika. Hasil analisis menunjukkan terdapat hubungan yang signifikan bagi beberapa item yang dipilih tetapi kekuatan hubungan korelasi adalah sederhana dan rendah.

Secara keseluruhannya, melalui pencapaian objektif kedua ini menunjukkan bahawa pengurusan landskap di Taman Ujana Rimba Tropika masih berada di tahap yang sederhana dengan nilai min 3.00. Kepuasan pengunjung sangat penting dalam mempengaruhi kehadiran pengunjung yang berterusan di masa akan datang. Hal ini kerana, pengunjung yang berpuas hati akan menyebarkan ilmu dan pengalaman yang diperoleh kepada ahli keluarga dan rakan-rakan bagi memperoleh pengalaman yang sama.

\section{Cadangan langkah penambahbaikan pengurusan landskap di Taman Ujana Rimba Tropika}

Secara keseluruhannya, cadangan penambahbaikan yang diberikan oleh responden merangkumi penambahbaikan kedua-dua jenis landskap iaitu landskap lembut dan landskap kejur yang terdapat di Taman Ujana Rimba Tropika. Hal ini kerana, landskap di taman rekreasi yang memasukkan elemen-elemen semula jadi dan landskap kejur menyebabkan pemandangannya kelihatan lebih cantik dan ceria (Azilah \& Raslinda, 2006). Selain itu, cadangan penambahbaikan ini merangkumi peranan semua pihak iaitu pihak Dewan Bandaraya Kota Kinabalu, peranan masyarakat dan peranan pihak kerajaan.

Seterusnya, majoriti responden menyatakan keperluan untuk membuat penambahbaikan bagi landskap kejur memandangkan kemudahan-kemudahan fizikal yang disediakan di Taman Ujana Rimba Tropika masih kurang memuaskan. Antaranya adalah kemudahan alat senaman yang tidak mencukupi. Oleh itu, pihak DBKK perlu memastikan bahawa kemudahan alat senaman adalah mencukupi serta menyediakan cara penggunaan alatan tersebut. Pengurusan taman permainan kanak-kanak juga dilihat masih berada pada tahap yang sederhana kerana terdapat alat permainan yang rosak dan tidak dapat digunakan. Keadaan ini memerlukan penyelenggaraan segera kerana taman permainan merupakan salah satu lokasi yang sering dikunjungi oleh pengunjung. Terdapat juga cadangan daripada responden yang menyatakan alat permainan perlu ditambah seperti buaian dan jongkang-jongket untuk kemudahan bermain bagi kanak-kanak. Permukaan lantai di taman permainan juga perlu diratakan kerana permukaan tanah yang berlubang membahayakan keselamatan kanak-kanak.

Selain daripada itu, kebanyakan responden juga mencadangkan pemasangan papan tanda di sekitar kawasan taman bagi tujuan amaran, pemberitahuan dan peringatan kepada pengunjung. Aspek keselamatan juga perlu dititikberatkan dalam pengurusan sebuah taman awam (Fauziah, 2016). Antara lokasi yang sering mendapat aduan dan kebimbangan dalam kalangan pengunjung adalah kawasan sekitar tasik. Keperluan untuk memasang tembok di sekeliling tasik sangat penting bagi menjamin keselamatan pengunjung serta mengelakkan risiko atau mengelakkan berlakunya insiden yang tidak diingini berlaku. Bukan itu sahaja, kerja-kerja pembersihan juga perlu dilaksanakan dengan lebih kerap terutama kawasan sekitar tasik dan tandas awam. Aspek kebersihan sememangnya memberi impak yang besar terhadap kepuasan pengunjung yang berkunjung ke taman awam. Pengawal keselamatan juga perlu disediakan bagi melakukan pemantauan dengan lebih kerap. Terdapat juga responden yang mencadangkan agar tempat letak 
kenderaan ditambah dan diperluaskan lagi kerana ruang tempat kenderaan adalah sempit dan ia menyukarkan pengunjung terutama ketika waktu puncak.

Selain daripada penambahbaikan terhadap kemudahan sedia ada, responden juga mencadangkan untuk menambah kemudahan lain bagi membolehkan pengunjung menjalankan pelbagai aktiviti. Antaranya adalah kemudahan berbasikal, air pancuran dan menyediakan watercolor di sekitar tasik untuk kemudahan pengunjung. Tambahan lagi, hasil kajian menunjukkan rata-rata responden tidak berpuas hati kerana kemudahan beribadat seperti surau tidak disediakan. Oleh yang demikian, kemudahan surau perlu dibina kerana ia merupakan salah satu keperluan pengunjung terutamanya yang beragama Islam. Selain itu, pihak DBKK perlu menyediakan kemudahan untuk golongan Orang Kurang Upaya (OKU) seperti tandas dan tempat letak kenderaan khas.

Namun begitu, usaha yang dilaksanakan oleh pihak berkuasa dalam mencapai pengurusan landskap yang baik tidak mampu dicapai tanpa bantuan dan kerjasama daripada masyarakat itu sendiri. Dengan itu, masyarakat perlu mengamalkan sikap yang baik seperti menjaga kebersihan taman dan mengelakkan daripada melakukan vandalisme. Masyarakat juga digalakkan untuk menyertai dan melibatkan diri dalam mana-mana aktiviti mahupun program penjagaan alam sekitar dan kemudahan taman awam yang dijalankan. Masyarakat juga berperanan untuk menjalankan aktiviti dan kempen alam sekitar dan menyebarkan kepentingan menjaga alam sekitar kemudahan orang awam.

Peranan pihak kerajaan juga memainkan peranan yang penting khususnya dalam menyebarkan pengetahuan terhadap kepentingan penjagaan alam sekitar melalui medium pendidikan. Hal ini kerana, pendidikan merupakan salah satu inisiatif jangka panjang yang dilaksanakan untuk menyampaikan pengetahuan berkenaan dengan alam sekitar yang merangkumi semua peringkat umur masyarakat. Di Malaysia, pendidikan alam sekitar dilihat sebagai satu usaha yang baik dalam menerapkan sikap dan amalan cintakan alam sekitar dalam kalangan masyarakat terutamanya pelajar. Walau bagaimanapun, usaha ini perlu dilaksanakan dengan lebih teliti dan menyeluruh agar ia bukan sahaja menyumbang kepada pengetahuan malah dapat dipraktikkan dalam kehidupan seharian masyarakat. Seterusnya, pihak kerajaan juga bertanggungjawab dalam melaksanakan pelbagai kempen dan program berkenaan alam sekitar. Di samping itu, penguatkuasaan undang-undang dan peraturan sedia ada perlu dilaksanakan dengan lebih tegas.

Oleh yang demikian, bagi memastikan pengurusan landskap di Taman Ujana Rimba Tropika berkualiti dan selaras dengan keperluan dan kehendak pengguna, maka pihak PBT seperti Dewan Bandaraya Kota Kinabalu (DBKK) haruslah melaksanakan pembangunan landskap sesuai dengan garis panduan yang telah dibentuk iaitu Garis Panduan Landskap Negara, 2008 dan Garis Panduan Perancangan Tanah Lapang dan Kawasan Rekreasi, 2013. Pengurusan landskap di taman ini perlu menjadikan garis panduan tersebut sebagai panduan dalam menjalankan kerja landskap lembut untuk pembangunan landskap yang menyeluruh terutamanya dari segi perancangan, reka bentuk asas, pemeliharaan dan pemuliharaan serta pemantauan kerja dan penyelenggaraan landskap lembut. Melalui penggunaan garis panduan ini dapat menyumbang kepada peningkatan pembangunan landskap di samping melaksanakan pembangunan fizikal yang seimbang dengan persekitaran hijau, indah dan dapat memelihara alam sekitar. 


\section{Kesimpulan}

Secara keseluruhannya, pengurusan landskap di sesebuah taman rekreasi awam sangat penting agar semua kemudahan yang disediakan selari dengan kehendak dan keperluan semasa pengunjung. Justeru itu, dalam merangka dan melaksanakan sesuatu pengurusan landskap di taman rekreasi awam, persepsi mahupun tahap kepuasan pengunjung adalah penting untuk membuat strategi yang berkesan di samping mampu memberi kepuasan yang maksimum kepada pengunjung. Pengurusan landskap taman rekreasi awam haruslah merangkumi keseluruhan landskap iaitu landskap lembut dan landskap kejur. Hal ini kerana kedua-dua elemen landskap ini bukan sahaja memberi kemudahan kepada pengunjung malah meningkatkan keindahan landskap taman awam. Dalam kajian yang dijalankan ini, pengkaji telah mencapai ketiga-tiga objektif kajian. Secara keseluruhannya, maklum balas yang diberikan oleh responden dilihat sangat penting untuk dijadikan rujukan bagi tujuan penambahbaikan di masa akan datang. Tahap kepuasan berkunjung secara tidak langsung akan mempengaruhi kunjungan ulangan pengunjung ke sesuatu destinasi. Pihak seperti Dewan Bandaraya Kota Kinabalu (DBKK) perlu mengambil tindakan segera bagi setiap masalah yang berkaitan dengan elemen-elemen landskap bagi memastikan tahap kepuasan kepada pengunjung dapat mencapai tahap kepuasan yang lebih tinggi daripada sebelumnya.

Keperluan dalam usaha penambahbaikan pengurusan landskap bukan sahaja menjamin tahap kepuasan pengunjung tetapi ia juga dapat menarik lebih ramai pengunjung ke Taman Ujana Rimba Tropika. Sesuai dengan matlamat kajian ini, cadangan bagi langkah penambahbaikan pengurusan landskap di Taman Ujana Rimba Tropika adalah agar penyediaan landskap yang dijalankan adalah selaras dengan pembangunan landskap seperti yang dinyatakan dalam Garis Panduan Landskap Negara. Walau bagaimanapun, untuk mencapai hasrat ini maka semua pihak haruslah bekerjasama dan mengambil bahagian dalam pengurusan sesebuah taman rekreasi awam. Selain daripada peranan pihak berkuasa tempatan, pengunjung juga haruslah memainkan peranan dalam menjaga kemudahan awam yang disediakan. Oleh yang demikian, setiap pihak yang terlibat secara langsung dengan kerja-kerja melaksanakan pengurusan dan penyelenggaraan landskap harus bekerjasama agar matlamat menjadikan Malaysia sebagai "Negara Taman" pada tahun 2005 dan "Malaysia Negara Taman Terindah" pada tahun 2020 mampu dicapai.

\section{Rujukan}

Carson, J. (1972). A national urban growth policy: meaning \& measures for its implementation. Presented paper to the 54th Annual Conference of the American Institute of Planners held in San Francisco, October 1971. Urban Land, 3-10 February.

Dasar Landskap Negara. (2010). www.kpt.gov.my. (10.12.2018).

Fauziah Che Leh. (2016). Pelancongan bandar dan isu keselamatan: Kajian kes pelancong antarabangsa Kuala Lumpur. Geografia-Malaysia Journal of Society and Space. 12(8), $110-122$.

Garis Panduan Landskap Negara (Edisi 2). (2008). Kuala Lumpur.

Garis Panduan Landskap Negara, Bahagian 3. (2008). Kuala Lumpur. 
Hamidi, I., Tuan Pah Rokiah, S.H., \& Johan Afendi, I. (2006). Pengurusan Persekitaran dan Pelancongan di Malaysia: Konsepsi dan Kajian. Sintok: Penerbit Universiti Utara Malaysia.

Idris, M. (2010). Pewartaan kawasan lapang di bawah Seksyen 62 Kanun Tanah Negara. Kajian kes: kawasan pentadbiran Majlis Daerah Pontian. Tesis Sarjana Universiti Teknologi Malaysia.

Jaffry, Z., \& Nor Azlina, H. (2004). Pelancongan Rekreasi Berasaskan Cabaran dan Biodiversiti: Isu dan Konflik. Kuala Lumpur.

Jeckie, P., \& Greg, P.S., (2018). Visitor satisfaction with a public green infrastructure and urban nature space in Perth, Western Australia. Land, 7(4), 159-172.

Johan Afendi, I. (2006). Pengenalan Kepada Tarikan Pelawat: Konsep dan Pengurusan. Dlm. Pengurusan Persekitaran dan Pelancongan di Malaysia: Konsepsi dan Kajian. Sintok: Penerbit Universiti Utara Malaysia.

Kamariyah Kamsah. (1983). Some Thought in Planning and Designing Towards A Society of Leisure and Recreation, Outdoor Recreation in Malaysia (Seminar Paper). UPM.

Lee Boon, H. (2007). Pembangunan Ekopelancongan di Cameron Highlands: Satu Kajian Kes. Universiti Sains Malaysia.

Nur Fateha, M. (2015). Fungsi dan Peranan Taman Rekreasi. Diperoleh Daripada http://dokumen.tips/documents/fungsidan-peranan-taman- rekreasi. (10.12.2018).

Putri Haryati. (2015). Masalah pengurusan kawasan lapang oleh pihak berkuasa tempatan di Malaysia. Serdang: Penerbit Universiti Pertanian Malaysia.

Ramkissoon, H., Smith, L., David, G., \& Kneebone, S., (2014). Visitor Satisfaction and Place Attachment in National Parks. Tourism Analysis, 19(3), 287-300.

Rooslinda Binti Mamat. (2002). Penyediaan dan pengurusan kawasan lapang perumahan, kajian kes: Mukim Batu, Gombak, Selangor. Pusat Pengajian Perumahan, Bangunan dan Perancangan Universiti Sains Malaysia Pulau Pinang

Rosniza Aznie, C.R, Mohd Azlan, A., Rozalini, R., Rosmiza, M.Z., Abdul Rahim, M.N., Mohd. Fuad, M.J., \& Novel, L. (2017). Potensi Tarikan Ekopelancongan Rekreasi di Taman Rekreasi Air Panas (TRAP) Sungai Klah, Perak. Geografia-Malaysian Journal of Society and Space, 8(7), 20-32.

Salingaros, N.A. (2005). Principles of Urban Structure. Amsterdam: Techne Press.

Sejarah Landskap. 2011. http://www.rahsiataman.com/sejarah/Sejarah.html. (10.12.2018).

Taro Yamane. (1967). Elementary Sampling Theory. Englewood Cliffs, NJ: Prentice Hall.

Utusan Online. (2015). Taman Rekreasi Mangsa Vandalisme. http://www. utusan.com.my/berita/wilayah/kl-putrajaya/taman-rekreasi-mangsa-vandalisme-1.98783

Wan Sabri, W.M., Mamit, J.D., Wah, L.S. \& Roslan, H. (1983). An Evaluation of Park Usage and Its Effect upon Planning and Management: The Templer Park Visitor Survey. Rekreasi Luar di Malaysia: 367-382. Fakulti Perhutanan, Universiti Pertanian Malaysia.

Zaimah, R., Er, A.C., Sarmila, M.S., Habibah, A., Hamzah, J., Nurain Sahazali, \& Nadiah Hanani Abdul Jalil (2015). Kepuasan pelancong dengan Melaka sebagai destinasi pelancongan lestari: Satu kajian persepsi. Geografia-Malaysia Journal of Society and Space, 11(1), 135-142. 